УДК $612.3 ; 591.132$

(C) 2013

Мироненко О. І., Булавкіна Т. П., кандидати сільськогосподарських наук

Полтавська державна аграрна академія

\title{
ВПЛИВ МІНЕРАЛЬНИХ НЕТРАДИЦЙНИХ КОРМОВИХ ДОБАВОК НА ОБМІН МАКРОЕЛЕМЕНТІВ В ОРГАНІЗМІ СВИНЕЙ
}

\section{Рецензент - кандидат сільськогосподарських наук О. І. Кравченко}

\begin{abstract}
Вивчення та аналіз впливу мінеральних нетрадиичійних кормових добавок: двокомпонентних композииій СМК (сухий мінеральний концентрат) із ліпротом, СМК з ехінацеєю пурпуровою та комплексної (СМК із ліпротом і ехінацеєю пурпуровою) на обмін окремих макроелементів, зокрема, кальцію, фосфору, калію, натрію та заліза, в організмі

свиней, а також їх вміст у хімусі шлунковокишкового тракту й сироватці крові. Досліджено та встановлено позитивний вплив пластової води на функціональний стан молодняку свиней і науково обтрунтовано введення ї̈ в необхідній кількості до складу кормової добавки раціону.
\end{abstract}

Ключові слова: кальиій, фосфор, калій, натрій, залізо, сухий мінеральний кониентрат, ехіначея пурпурова, мінералізовані пластові води, ліпрот, комплексна кормова добавка, комплексний біологічно активний препарат, поросята.

Постановка проблеми. В умовах інтенсивного використання тварин у разі обмеженого набору основних кормових інгредієнтів у їх раціонах збільшується вірогідність нестачі мінеральних речовин. Тому для проведення спеціальних досліджень із визначення рівня придатності природної сировини для використання в ролі іiї як мінеральних добавок, а також пошуку нових, нетрадиційних шляхів у вирішенні екологічних проблем на території України має актуальний характер.

Оскільки до цього часу недостатньо досліджена проблема впливу природних мінералів, зокрема мінералізованої пластової води у поєднанні з протеїном мікробіологічного походження та стимулюючими рослинними компонентами, що впливають на підвищення резистентності організму тварин, виникла необхідність вивчення впливу мінеральних нетрадиційних кормових добавок на обмін окремих мікроелементів, зокрема, кальцію, фосфору, калію, натрію та заліза в організмі свиней.

Аналіз останніх досліджень і публікацій, у яких започатковано розв'язання проблеми. За останні роки з'явилося чимало досліджень i науково обгрунтованих рекомендацій, стосуються застосування різних мінеральних нетрадицій- них кормових добавок до раціону молодняку свиней $[1,3-5]$. У зв'язку з посиленням екологічних вимог щодо інгредієнтів різних кормових добавок природного й синтетичного походження проблема використання екологічно чистої продукції набула особливої актуальності. Не зважаючи на те, що мінеральна годівля тварин енергетичної поживності не має, їй належить важлива роль у забезпеченні обмінних процесів у організмі. Окремими вченими доведено, що мінеральні добавки суттєво підвищують ефективність використань концентрованих кормів у тваринництві $[4,8]$. Однак, всебічні комплексні біохімічні й фізіологічні дослідження 3 впливу нетрадиційних біологічно активних кормових добавок на процеси травлення та обміну речовин у тварин проводяться недостатньо. Рішення цих питань дає змогу правильно і більш ефективно використовувати кормові добавки.

Мета дослідження - вивчення та аналіз впливу мінеральних нетрадиційних кормових добавок - двокомпонентних композицій (СМК (сухий мінеральний концентрат) із ліпротом, СМК із ехінацеєю пурпуровою, ліпрот 3 ехінацеєю пурпуровою) та комплексної (СМК із ліпротом і ехінацеєю пурпуровою) - на обмін окремих макроелементів, зокрема, кальцію, фосфору, калію, натрію та заліза в організмі свиней.

До завдань досліджень входило:

- визначення обміну кальцію, фосфору, калію, натрію і заліза у поросят під дією досліджуваних кормових добавок;

- визначення концентрації кальцію, фосфору, калію, натрію та заліза у хімусі поросят за введення досліджуваних нами кормових добавок методом накладання фістул на кишково-травний канал;

- визначення у сироватці крові піддослідних тварин вмісту кальцію, фосфору, калію, натрію та заліза.

Матеріали і методика досліджень. Дослідження виконувалися на базі лабораторії фізіології відтворення і трансплантації ембріонів, зоохімічного аналізу та експериментальної бази Інституту свинарства ім. О. В. Квасницького УААН. 
У фізіологічних обмінних дослідах вивчали вплив кормових мінеральних добавок на обмін кальцію, фосфору, калію, натрію та заліза в організмі молодняку свиней. Дослід проводився за методикою М. А. Коваленка [7]. Було сформовано три групи тварин-аналогів по чотири голови у кожній. Годівля поросят здійснювалася згідно 3 нормами годівлі свиней відповідного віку.

В експериментах із вивчення травлення у піддослідних тварин використовували методику накладання фістул на порожню та клубову кишки й шлунок за О. В. Квасницьким [2].

У сироватці крові та хімусі шлунковокишкового тракту вміст кальцію визначали за реакцією з окрезолфталеїнкомплексоном; вміст фосфору - за Фіске-Субарроу; вміст заліза проводили методом атомної абсорбційної спектрофотометрії; калію й натрію - методом полум'яної фотометрії; активність аланін- та аспартатамінотрансфераз визначали динітрофенілгідразиновим методом за Райтманом-Френкелем [6].

Результати досліджень. У результаті згодовування тваринам двохкомпонентної та комплексної кормової добавки кількість мінеральних елементів у кормах тварин дослідних і контрольної груп відрізнялася несуттєво (крім вмісту калію). Рівень мінеральних елементів у раціоні виявив вплив на краще засвоєння фосфору, калію та натрію. Порівняно 3 контролем, в організмі поросят другої дослідної групи засвоєння фосфору було більше на $10,4 \%(\mathrm{p} \leq 0,05)$, калію - на $49,1 \%(\mathrm{p} \leq 0,01)$ і натрію - на $21,6 \%(\mathrm{p} \leq 0,01)$. За кількістю калію у першій дослідній групі нами відмічено збільшення на 54,9 \% ( $\leq \leq 0,01)$.

За коефіцієнтами засвоєння мінеральних елементів рівень їх був у цілому найвищим у другій дослідній групі, порівняно 3 контрольною та першою. Однак між двома дослідними групами за такими показниками, як калій та залізо, спостерігалося незначне збільшення в першій, де задавали СМК із ліпротом (див. рис.).

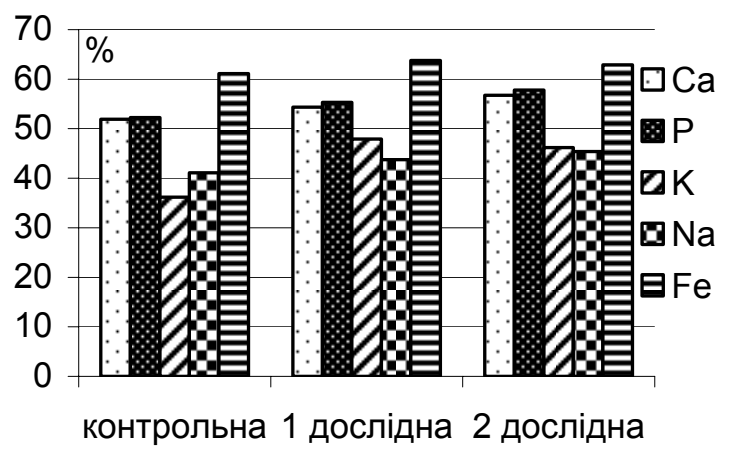

\section{Рис. Засвосння мінеральних елементів за дії кормових добавок}

Отже, згодовування тваринам комплексної кормової добавки (СМК, ліпрот та ехінацея пурпурова) порівняно з двокомпонентною (ліпрот і ехінацея пурпурова) сприяло в основному одержанню кращих показників за перетравністю поживних речовин, засвоєнням азоту та мінеральних елементів і в результаті - ростом поросят.

Таким чином, використовуючи класичну методику щодо виконання операцій із накладання фістул на шлунок і тонкий кишечник проведені дослідження за дії нових нетрадиційних екологічно безпечних кормових добавок у раціонах поросят, нами вдалося встановити фізіологічні закономірності мінерального обміну в процесах їх травлення.

Відмічені особливості вмісту мінеральних елементів у травному тракті доповнюють також і рівень процесів обміну їх під впливом різних композиційних кормових добавок у раціоні поросят. 3'ясовано, що в процесі травлення - в залежності від складу кормової добавки та співвідношення між його компонентами - змінюється і концентрація досліджуваних мінеральних речовин у хімусі.

Під дією комплексної кормової добавки, що іiі отримували тварини третьої дослідної групи, простежується вірогідне збільшення концентрації мінеральних елементів у досліджуваних відділах шлунково-кишкового тракту. Водночас не встановлено значних змін за кількістю кальцію та фосфору в хімусі шлунка, калію - у порожній кишці й фосфору - в клубовій.

Встановлені зміни концентрації мінеральних елементів у хімусі шлунку та порожньої кишки. У контрольній групі впродовж дослідного періоду за сумарною концентрацією мінеральних елементів у хімусі між шлунком і порожньою кишкою встановлена суттєва різниця: зменшується вміст кальцію на $35,43 \%(\mathrm{p} \leq 0,01)$, заліза - 23,21 \% $(\mathrm{p} \leq 0,001)$, а фосфору та натрію збільшується на $34,49 \%(\mathrm{p} \leq 0,01)$ і $35,55 \%$ ( $\mathrm{p} \leq 0,01)$ відповідно.

У хімусі порожньої кишки зменшилася концентрація кальцію $(\mathrm{p} \leq 0,05)$, заліза $(\mathrm{p} \leq 0,001)$, а фосфору й натрію, навпаки, збільшилася $(\mathrm{p} \leq 0,01)$, порівняно 3 показниками хімусу шлунка; у клубовій кишці вірогідно знизилася кількість кальцію та фосфору ( $\leq \leq 0,001)$, а калію підвищилась $(\mathrm{p} \leq 0,05)$.

Порівняно $з$ контрольною групою в тварин, у раціоні яких була комплексна добавка, калію в хімусі шлунку було більше на 29,0 \%, натрію на $26,5 \%(\mathrm{p} \leq 0,05)$, заліза - на $11,0 \%(\mathrm{p} \leq 0,01)$. Вміст кальцію у хімусі порожньої кишки на 20,1 \% $(\mathrm{p} \leq 0,05)$ був більшим, фосфору - на $15,3 \%$ $(\mathrm{p} \leq 0,01)$, натрію - на $34,0 \%(\mathrm{p} \leq 0,01)$, заліза - 
СІЛЬСЬКЕ ГОСПОДАРСТВО. ТВАРИННИЦТВО

Мінеральний склад сироватки крові піддослідних поросят (n=5; $M \pm m)$

\begin{tabular}{|c|c|c|c|}
\hline Показник & Контрольна група & Дослідна група & Порівняно з контролем, \% \\
\hline Кальцій, ммоль/л & $2,70 \pm 0,02$ & $2,83 \pm 0,08$ & 104,81 \\
\hline Фосфор, ммоль/л & $1,27 \pm 0,02$ & $1,52 \pm 0,11^{*}$ & 119,68 \\
\hline Калій, ммоль/л & $4,80 \pm 0,55$ & $6,03 \pm 0,55^{*}$ & 125,62 \\
\hline Натрій, ммоль/л & $140,47 \pm 8,43$ & $165,36 \pm 10,85^{*}$ & 117,72 \\
\hline Залізо, мкмоль/л & $62,46 \pm 10,22$ & $109,22 \pm 34,71^{*}$ & 174,86 \\
\hline
\end{tabular}

Примітка: * - $\leq 0,05$ - вірогідність різниці між показниками контрольної і дослідних груп

на $13,2 \%(\mathrm{p} \leq 0,01)$. Водночас концентрація кальцію у клубовій кишці зросла на $23,9 \%(\mathrm{p} \leq 0,05)$, калію - на 33,6 \% (p $\leq 0,01)$, натрію - на $34,6 \%$ $(\mathrm{p} \leq 0,01)$, заліза - на $12,3 \%(\mathrm{p} \leq 0,05)$. Показники коефіцієнтів кореляції в контрольній групі між вмістом кальцію, фосфора, калію, натрію та заліза у шлунку, а також у порожній та клубовій кишках відповідають середньому і сильному зв'язку. У поросят, у раціоні яких була комплексна добавка, такі зв'язки посилювалися.

Застосування КБАП позитивно позначилося на мінеральному складі крові дослідних поросят на дорощуванні (див. табл.). Аналіз даних таблиці показує, що кількість мінеральних речовин у сироватці крові в разі включення в раціон комплексного біологічно активного препарату (КБАП) достовірно підвищується: концентрація фосфору зросла - на 19,7 \%, калію - на 25,6 \%, натрію - на 17,7 \% $(\mathrm{p} \leq 0,05)$, заліза - на 74,9\% ( $\leq \leq 0,01)$. Такі результати, $з$ нашого погляду, можна пояснити насиченістю раціонів мінеральними речовинами, що забезпечило збільшення активності проміжного обміну макроелементів у поросят.

Висновки: 1. Згодовування тваринам кормових добавок: двокомпонентних композицій СМК (сухий мінеральний концентрат) із ліпротом,

\section{БІБЛІОГРАФІЯ}

1. Ібатуллін I. I. Ефективність використання лізін-протеїнової кормової добавки - ліпрот при відгодівлі молодняку свиней / I. І. Ібатуллін, М. Я. Кривенок // Науковий вісник НАУ : Зб. наук. праць. - К., 1998. - Вип. 3. - С. 78-81.

2. Квасницкий А. В. Физиология пищеварения у свиней / А. В. Квасницкий. - М., 1951. - 228 с.

3. Кокорев В. А. Биологическое обоснование потребности супоросных свиноматок в макроэлементах / [Под. ред. С. А. Лапшина]. - Саранск : Изд-во Сарат. ун-та, 1990. - 172 с.

4. Кулик М. Ф. Традиційні і нетрадиційні мінерали у тваринництві // М. Ф. Кулик, Т. В. Засуха, І. М. Величко [та ін.] - К. : Сільгоспосвіта, 1995. C. 4-5.

5. Кушнір B. I. Перетравність поживних речовин, обміну азоту та окремих мінеральних елементів
СМК 3 ехінацеєю пурпуровою та комплексної (СМК із ліпротом і ехінацеєю пурпуровою) на обмін окремих макроелементів, зокрема, кальцію, фосфору, калію, натрію та заліза, сприяло в основному одержанню кращих показників обміну мінеральних елементів в організмі свиней.

2. 3'ясовано, що в процесі травлення в залежності від складу кормової добавки та співвідношення між його компонентами змінюється $\mathrm{i}$ концентрація досліджуваних мінеральних речовин у хімусі. У цілому відмічено значне коливання показників між найменшими і найбільшими концентраціями (кальцію, фосфору та заліза майже вдвічі, а калію і натрію - втричі).

3. За згодовування запропонованого нами комплексного біологічно активного препарату КБАП результати гематологічних досліджень (мінерального складу) показали, що даний препарат не має негативного впливу на фізіологічний стан тварин, водночас підвищує вміст досліджуваних мікроелементів у сироватці крові. Так, концентрація заліза, порівняно $з$ контрольними тваринами, збільшилася у дослідній групі на 74,9\% $(\mathrm{p}<0,01)$, фосфору - на 19,7 \% (p<0,05), калію на 25,6 \% $(\mathrm{p}<0,05)$ і натрію - на $17,7 \%(\mathrm{p}<0,05)$.

при згодовуванні природних мінералів : автореф. дис. ... канд. с.-г. наук : спец. 06.00.16. «Годівля тварин і технологія кормів» / В. І. Кушнір. - Вінниця, 1997. - 19 с.

6. Клиническая лабораторная диагностика в ветеринарии : Справочное издание / И. П. Кондрахин, Н. В. Курилов, А. Г. Малахов [и др.] - М. : Агропромиздат, 1985. - 287 с.

7. Методики исследований по свиноводству / За ред. Ф. К. Почерняева. - Харьков, 1977. - 151 с. 8. Мироненко О. I. Фізіологічні особливості травлення у поросят під впливом окремих нетрадиційних кормових добавок : автореф. дис. ... канд. с.-г. наук: спец. 03.00.13. «Фізіологія людини і тварин»/ О. І. Мироненко. - Полтава, 2009. -20 c. 